\title{
INKSTŲ FUNKCIJOS VERTINIMAS, DOZUOJANT VAISTUS
}

\author{
Armantas Gintautas, Tomas Janušonis \\ Klaipédos universitetinès ligoninès Anesteziologijos ir reanimatologijos klinika
}

Raktažodžiai: kreatinino klirensas, glomerulų filtracijos greitis, inkstų nepakankamumas, inkstų funkcijos sutrikimas, farmakokinetika.

\begin{abstract}
Santrauka
Inkstų funkcija yra ypač svarbi, dozuojant vaistus. Siekiant išvengti per mažos ar per didelès dozès nepakankamo veiksmingumo ar nepageidaujamo poveikio, būtina kuo tiksliau ịvertinti inkstų funkciją ir, remiantis preparato charakteristikų santraukoje pateiktomis rekomendacijomis, koreguoti dozę. Šio straipsnio tikslas - pristatyti inkstų funkcijos vertinimo metodus vaistų dozei parinkti, atsižvelgiant ị inkstų funkciją. Šiame straipsnyje apžvelgiami inkstų funkcijos vertinimo metodai, analizuojami jų privalumai ir trūkumai bei veiksniai, darantys įtaką inkstų funkcijos skaičiavimo rezultatams, remiantis naujausiais literatūros duomenimis. Pateikiami pagrindiniai vaistų dozavimo principai esant inkstų funkcijos sutrikimui ir nagrinejjami su inkstų funkcijos ịvertinimo metodo taikymu susiję galimi prieštaravimai, dozuojant vaistus. Pateikiamos geriamụjų antikoaguliantų dozavimo, esant inkstų funkcijos sutrikimams, rekomendacijos. Daroma išvada, kad idealaus inkstų funkcijos ịvertinimo metodo nèra, ir skiriant bet kokị vaistą, reikia peržiūrèti preparato charakteristiku santrauką ir ịvertinti ne tik dozavimo rekomendacijas esant inkstų funkcijos sutrikimui, bet ir inkstų funkcijos vertinimo metodą.
\end{abstract}

\section{Ivadas}

Dauguma ịprastai vartojamų vaistų ar jų aktyvių metabolitų išskiriami per inkstus. Tai ypač svarbu žmonėms, kurių sutrikusi inkstų funkcija. Inkstų funkcijos sutrikimas keičia vaistų farmakokinetiką, o tai gali daryti įtaką jų veiksmingumui ir didinti nepageidaujamo poveikio riziką [1]. Vaistai dažnai skiriami pacientams, kurie serga lètine ar ūmine inkstu liga, todèl didejja nepageidaujamų reakcijų rizika [2]. Priklausomai nuo inkstų funkcijos sutrikimo sunkumo, gali tekti mažinti vartojamo vaisto dozę ir (arba) intervalą tarp dozių vartojimo. Gydant pacientus, kurių inkstų funkcija sutrikusi, pasitaikančios dozavimo klaidos gali lemti nepageidaujamo poveikio pasireiškimą bei nepalankią gydymo baigtị (ypač jei siauras vaisto terapinis indeksas) [3]. Pacientams, kurių inkstų funkcija sutrikusi, ypač svarbu tinkamai ją įvertinti, kad būtų galima koreguoti dozavimą, remiantis vaisto skyrimo rekomendacijomis.

Darbo tikslas - pristatyti inkstų funkcijos vertinimo metodus vaistų dozei parinkti, atsižvelgiant ị inkstų funkciją, apžvelgti jų privalumus, trūkumus ir prieštaravimus bei pateikti geriamujų antikoaguliantų dozavimo esant inkstų funkcijos sutrikimams rekomendacijas (kaip reprezentatyvu pavyzdi).

\section{Tyrimo medžiaga ir metodai}

Mokslinès literatūros paieška atlikta nacionalinejje Lietuvos akademinejje elektroninejje bibliotekoje eLABa ir duomenų bazèje PubMed. I sisteminę apžvalgą itraukti 24 straipsniai, kuriuose analizuojama aptariama tema.

\section{Tyrimo rezultatai}

Inkstų funkcijos vertinimas. Klinikinèje praktikoje inkstų funkcija dažniausiai vertinama netiesiogiai: apskaičiuojamas kreatinino klirensas (aKK) ar glomerulų filtracijos greitis (aGFG). Kreatinino klirensas (KK) yra kraujo plazmos tūris, iš kurio pašalinamas kreatininas per laiko vienetą. Kreatininas susidaro vykstant kreatino metabolizmui griaučių raumenyse bei iš mèsos, suvartotos maistui. I kraują kreatininas išsiskiria pastoviu greičiu ir jo koncentracija plazmoje būna pakankamai stabili. Kreatininas filtruojamas glomeruluose (apie 85 proc.), kita dalis (apie 15 proc.) sekretuojama nefrono proksimaliniuose kanalëliuose. Inkstuose kreatininas nèra reabsorbuojamas ir metabolizuojamas. Dèl šių priežasčių kreatinino koncentracija naudojama inkstų funkcijai ịvertinti. KK galima apskaičiuoti ir tiesiogiai, surenkant paros šlapimą ir jame nustatant kreatinino kiekį, tačiau tai labai nepatogu (ypač ambulatorinèmis sąlygomis), be to, galimi ịvairūs netikslumai renkant paros šlapimą, kurie gali iškreipti rezultatus. Dèl šių priežasčių KK apskaičiuoti paprastai naudojama Cockroft-Gault (CG) formulè (1 pav.) [4]. Taikant šią formulę, inkstų funkcija vertinama atsižvelgiant ne tik į kreatinino koncentraciją serume, bet ir 
i veiksnius, lemiančius raumenų masę, tokius kaip amžius, kūno svoris, lytis. Svarbu atkreipti dèmesį, kad CG matavimo vienetas yra $\mathrm{ml} / \mathrm{min}$. Glomerulų filtracijos greitis (GFG) yra suminis visų funkcionuojančių nefronų filtracijos greitis, kurio tiesiogiai įvertinti nèra galimybès. Tiksliausiai GFG galima nustatyti naudojant egzogeninius idealius filtracinius žymenis, tokius kaip kaip inulinas, jotalamatas ar joheksolis, kurie yra visiškai filtruojami glomeruluose (nèra sekretuojami ir reabsorbuojami), tačiau toks GFG ịvertinimas yra gana sudètingas ir klinikinejje praktikoje nedažnai taikomas [5]. Tradiciškai GFG apskaičiuoti naudojami endogeniai filtraciniai žymenys, tokie kaip kreatininas [6]. Dažniausiai GFG apskaičiuoti naudojamos MDRD (angl. modification of diet in renal disease), paprastoji ar sudetingoji, ir CKDEPI (angl. chronic kidney disease epidemiology collaboration) formulès (1 pav.). Inkstų funkcija yra proporcinga inkstų dydžiui, kuris proporcingas kūno paviršiaus plotui. Vidutinis jauno suaugusio žmogaus kūno paviršiaus plotas yra $1,73 \mathrm{~m}^{2}$, GFG skaičiuojamas $1,73 \mathrm{~m}^{2}$. Naudojant šias formules, atsižvelgiama ị amžių, rasę, lytị ir jų matavimo vienetas yra $\mathrm{ml} / \mathrm{min} / 1,73 \mathrm{~m}^{2}[7,8]$. Klinikinejje praktikoje aGFG dažniausiai naudojamas lètinès inkstų ligos (LIL) progresavimui ịvertinti [9].

Šios formulès tinkamos naudoti tik tada, kai inkstų funkcija stabili ir kreatinino koncentracija kraujo serume nekinta (ji gali būti nestabili, pvz., dèl greitai kintančios inkstų funkcijos dauginio organų disfunkcijos sindromo metu, reikšmingų organizmo skysčių balanso pokyčių ir t.t.) [9]. Inkstų funkcijai vertinti naudojama kreatinino koncentracija kraujo serume, todèl apskaičiuotam rodmeniui didelę itaką daro veiksniai, keičiantys kreatinino kiekị. Pavyzdžiui, labai svarbus veiksnys yra kreatinino sekrecijos kanalèliuose sumažèjimas ar padidèjimas (glomerulų filtracijos greičiui mažèjant, santykinè nefrono proksimaliniuose kanalèliuose sekretuojamo kreatinino dalis didejja). Svarbūs yra ir su kreatinino koncentracijos kraujo serume nustatymu susiję netikslumai (nustatymo metodas, standartizacija, paklaidos). Būtina įvertinti ir būkles, kurių metu padideja (pvz., esant rabdiomiolizei, didelei raumenų masei, vartojant didelį kiekị baltymų su maistu ar kreatino papildus) ar sumažeja (pvz., esant raumenu atrofijai) kreatinino susidarymas organizme, nes tokiais atvejais gali būti klaidingai diagnozuojamas arba nediagnozuojamas inkstų funkcijos nepakankamumas $[9,10]$. Kreatinino koncentracijos kraujo serume rodmeniui įtakos gali turèti daug endogeninių ir egzogeninių medžiagų (1 lentelè) [9].

Inkstų funkcijos vertinimo paklaidą gali lemti ne tik kreatinino koncentracijos pokyčiai kraujo serume bei jos

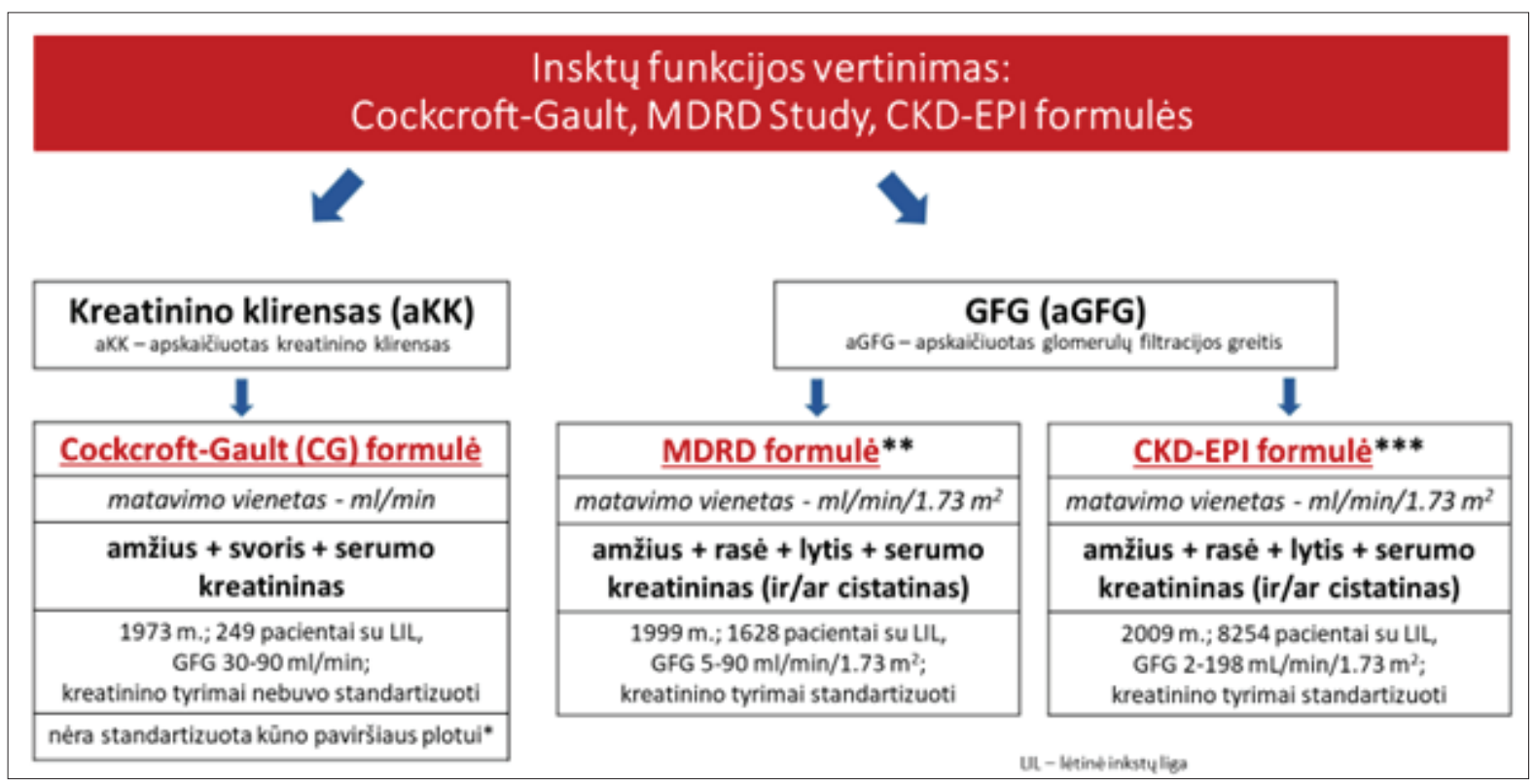

1 pav. Formulès, dažniausiai naudojamos inkstų funkcijai ịvertinti

* Nebuvo standartizuoti kuriant formulę naudoti kreatinino kiekio rodmenys ir gauta duomenu, kad kreatinino koncentracija nustačius šiuo metu taikomais metodais, gautas rezultatas bus 10-20\% mažesnis, nei buvo gautas kuriant formulę; ** Mažiau tiksli, kai GFG>60 ml/min./1,73 m²;** Labiau tiksli, kai GFG $>60$ $\mathrm{ml} / \mathrm{min} . / 1,73 \mathrm{~m}^{2}$.

Šaltiniai: Cockcroft DW, Gault MH. Prediction of creatinine clearance from serum creatinine. Nephron. 1976;16(1):31-41; Levey AS, Coresh J, Greene T, et al. Using standardized serum creatinine values in the Modification of Diet in Renal Disease Study equation for estimating glomerular filtration rate. Ann Intern Med. 2006; 145(4):247-254. 
1 lentelè. Kai kurių endogeninių ir egzogeninių medžiagų įtaka nustatomam kreatinino koncentracijos kraujo serume rodmeniui Šaltinis: Kidney Disease: Improving Global Outcomes (KDIGO) CKD Work Group. KDIGO 2012 clinical practice guideline for the evaluation and management of chronic kidney disease. Kidney Int Suppl 2013; 3: 1-150.

\begin{tabular}{|c|c|}
\hline $\begin{array}{l}\text { Medžiagos, didinančios } \\
\text { kreatinino kiekị kraujyje }\end{array}$ & $\begin{array}{l}\text { Medžiagos, mažinančios } \\
\text { kreatinino kiekị kraujyje }\end{array}$ \\
\hline $\begin{array}{l}\text { Fenofibratas (didina kreati- } \\
\text { nino koncentraciją) } \\
\text { Cefazolinas (dėl laboratorinès } \\
\text { sąveikos) } \\
\text { Lidokainas (dèl laboratorinès } \\
\text { sąveikos) } \\
\text { Ranitidinas (dèl sekrecijos } \\
\text { kanalëliuose slopinimo) } \\
\text { Trimetoprimas (slopina sekre- } \\
\text { ciją kanalèliuose) } \\
\text { Aspirinas, acetoaminofenas, } \\
\text { metamizolas (dèl laboratori- } \\
\text { nės sąveikos, jei naudojamas } \\
\text { Jaffe metodas) } \\
\text { Gliukozè (dèl laboratorinės } \\
\text { sąveikos) }\end{array}$ & $\begin{array}{l}\text { Dopaminas (dèl laboratorinès } \\
\text { sąveikos) } \\
\text { Dobutaminas (dèl laboratorinès } \\
\text { sąveikos) } \\
\text { Furozemidas (dèl laboratorinès } \\
\text { sąveikos) } \\
\text { Bilirubinas (dèl laboratorinès są- } \\
\text { veikos) }\end{array}$ \\
\hline
\end{tabular}

nustatymo tikslumas, tačiau ir kiti su pacientu susiję veiksniai. Pastebèta, kad visos šiuo metu klinikinèje praktikoje naudojamos formulès inkstų funkcijai vertinti nepritaikytos specifinėms pacientų grupėms, pvz., senyviems ar nutukusiems žmonėms. Senyviems žmonėms kreatinino koncentracija paremtas inkstų funkcijos įvertinimas būna netikslus. Pvz., jei naudojama CKD-EPI ar MDRD formule, aGFG būna didesnis, nei realus, todèl senyviems žmonèms siūloma naudoti alternatyvius žymenis, pvz., cistatiną C. Iš šiuo metu naudojamų formulių inkstų funkcijai ịvertinti, senyviems žmonėms tiksliausi rezultatai gaunami naudojant CKD-EPI formulę [11]. GFG didèja, didèjant kūno dydžiui, tačiau toks didèjimas proporcingas ne absoliučiam kūno svoriui, o kūno svoriui, atmetus riebalini sluoksnį (angl. lean body weight, LBW) ir kūno paviršiaus plotą. Apskaičiuojant KK pagal CG formulę ir naudojant absoliutų kūno svorị, rezultatas tampa netikslus, tad rekomenduojama naudoti LBW. Naudojant GFG formules, nutukusiems žmonèms gaunamas per didelis GFG, nes neịvertinamas kūno paviršiaus ploto padidejimas, todèl tikslesni rodmenys gaunami pritaikius indeksaciją pagal kūno paviršiaus plotą [12].

Vaistų dozavimo principai, esant inkstų funkcijos sutrikimui. Sutrikus inkstų funkcijai, pailgeja vaistų ar jų metabolitų, kurie daugiausia išskiriami per inkstus, pusinès eliminacijos laikas. Laikoma, kad jei per inkstus išsiskiria $\geq 30 \%$ nepakitusio vaisto arba veiksmingų ar toksini poveiki sukeliančių vaisto metabolitų, gali pasireikšti kliniškai reikšmingas kaupimasis, nors vienkartinès vaisto dozès nèra pavojingos [13]. Dozavimą būtina koreguoti, jei vartojamos kartotinès vaisto dozès. Esant inkstų funkcijos sutrikimui, galimi du vaisto dozès modifikavimo būdai: ịprastiniais intervalais vartojama mažesnè dozė arba ilgesniais intervalais vartojama ịprastiné dozė [14]. Kartais taikomas kombinuotasis metodas, t. y. ilgesniais intervalais vartojama sumažinta vaisto dozè. Jeigu reikia palaikyti vaisto koncentraciją serume tarp dozių vartojimo, iprastiniais intervalais vartojama sumažinta dozè, o jei būtina pasiekti tam tikrą didžiausią vaisto koncentraciją serume - vartojama ịprastiné dozè ilgesniais intervalais [15]. Taikant pastarają schemą, didžiausia ir mažiausia vaisto koncentracija serume būna panaši i nustatomą pacientams, kurių inkstų funkcija normali [16].

Kokią formulę naudoti inkstų funkcijai įvertinti, dozuojant vaistus? $1998 \mathrm{~m}$. Amerikos maisto ir vaistų administracija (FDA) CG formulę patvirtino kaip standartinę inkstų funkcijai ịvertinti dozuojant vaistus ir iki 2008 m. rekomendavo naudoti tik šią formulę. Nors yra priimta, kad MDRD ir CKD-EPI formulès gali būti naudojamos apskaičiuoti vaistu dozes esant inkstų funkcijos sutrikimui, CG išlieka tiek FDA, tiek ir Europos vaistų agentūros (EMA) rekomendacijose iki šių dienų [17,18]. Daugelis tarptautinių organizacijų savo rekomendacijose nurodo, kad daugumai pacientų skirtingais metodais ịvertinta inkstų funkcija klinikinejje praktikoje (pvz., naudojant CG, MDRD ar CKD-EPI formulę)
2 pav. Simuliacinis inkstų funkcijos ịvertinimo pavyzdys

\section{$64 \mathrm{ml} / \mathrm{min}$. $67 \mathrm{ml} / \mathrm{min}$.}

Tiesioginiam aGFG ir aKK rodiklių palyginimui, GFG rodmuo pritaikomas konkrečiam pacientui, rodmenj išreiškiant $\mathrm{ml} / \mathrm{min}$ (atmetamas kūno paviršiaus plotas). Kūno svoris $(60 \mathrm{~kg})+$ ūgis $(170 \mathrm{~cm})$ 
nelemia vaistų dozavimo skirtumų. Dozuojant vaistus, galima apskaičiuoti tiek KK (išreikštas ml/min), tiek GFG (išreikštas $\mathrm{ml} / \mathrm{min} / 1,73 \mathrm{~m}^{2}$ ) rodmeni. Rekomendacijose taip pat nurodoma, jei paciento kūno svoris yra labai didelis arba labai mažas, o apskaičiuojamas GFG, rodmenį reikia adaptuoti atmetant kūno paviršiaus plotą, kad jis būtų išreikštas ml/ min. Jei skiriami siauro terapinio indekso vaistai (t.y. kai net nedidelis perdozavimas gali lemti toksinị poveikị), inkstų funkciją reikia vertinti naudojant egzogeninius filtracijos žymenis, nes kreatininu paremtas inkstų funkcijos įvertinimas gali būti netikslus $[21,22]$. Kyla klausimas, ar tikrai klinikinejje praktikoje nèra skirtumo, kuri formulè bus pasirinkta inkstų funkcijai ịvertinti, dozuojant vaistus? Irodyta, kad skirtingais metodais ịvertintos inkstų funkcijos rodmenys gali būti labai skirtingi $[19,20]$. Atliktas tyrimas parodè, kad formulès pasirinkimas turejjo įtakos vyresnių kaip 65 metų pacientų analgetikų dozès koregavimui. Iš 790 hipotetiniu pacientų 59,3 proc. buvo priskirti 3-5 lètinès inkstų ligos stadijai pagal CG formulę, kai taikant MDRD ir CKD-EPI, šiai stadijai priskirta 27,1 ir 33,1 proc. pacientų. Didžiausia gabapentino $1800 \mathrm{mg}$ dozè, atsižvelgiant ị inkstų funkciją pagal vaisto skyrimo rekomendacijos, galèjo būti skiriama 7 pacientams pasirinkus CG formulę, 41 pacientui - MDRD formulę, 15 pacientų - CKD-EPI formulę. Tyrëjai pastebèjo, kad formulès pasirinkimas apskaičiuojant inkstų funkciją daro reikšmingą ịtaką gabapentino dozavimui [23]. Simuliacinis pavyzdys, kaip hipotetiniam pacientui panaudojus skirtingas inkstų funkcijos įvertinimo formules gaunamas skirtingas rodmuo, lemiantis, ar X vaistas bus skirtas gydymui pagal rekomendacijas, pateikiamas 2 paveiksle. Tarkime, remiantis X vaisto charakteristikų santrauka, jo negalima skirti, kai aGFG yra mažiau kaip $65 \mathrm{ml} / \mathrm{min}$. Pasirinkus CG formulę ir apskaičiuojant KK, gaunamas rodmuo yra 55,25 $\mathrm{ml} / \mathrm{min}$. Apskaičiuojant GFG ir renkantis MDRD ar CKDEPI, gaunami rodmenys yra $65 \mathrm{ml} / \mathrm{min} / 1,73 \mathrm{~m}^{2}$ ir $68 \mathrm{ml} /$ $\mathrm{min} / 1,73 \mathrm{~m}^{2}$. X vaisto charakteristikų santraukoje nurodytas matavimo vienetas $\mathrm{ml} / \mathrm{min}$. Remiantis rekomendacijomis, norint palyginti aGFG su aKK, reikia atmesti kūno paviršiaus plotą ir perskaičiuoti aGFG ị ml/min. Atmetus kūno paviršiaus plotą, pagal MDRD aGFG yra $64 \mathrm{ml} / \mathrm{min}$, pagal CKD-EPI - $67 \mathrm{ml} / \mathrm{min}$. Reikia spręsti, kurią formulę (leidžiančią ar ribojančią X vaisto skyrimą) pasirinkti hipotetinio paciento inkstų funkcijai vertinti. Ivairiuose šaltiniuose pateikiama informacija apie vaistų dozavimą sutrikus inkstų funkcijai ir rekomendacijos, kokią formulę pasirinkti apskaičiuojant inkstų funkciją konkrečiam vaistui, gali skirtis. Tyrimas, kurio autoriai palygino JAV naujai užregistruotų 44 vaistų dozavimo informaciją jų charakteristikų santraukose ir ịvairiuose vaistų žinynuose, parodè skirtumus ir neatitikimus. Tyrejų nuomone, pagrindinis šaltinis, kuriuo galima vadovautis, yra vaistų charakteristikų santrauka, nors kai kuriose iš jų trūko aiškios informacijos, kaip dozuoti ir kokią formulę naudoti, esant inkstų funkcijos sutrikimui [24]. Vaistinio preparato informaciniuose dokumentuose dažnai

2 lentelè. Geriamųjų antikoaguliantų dozavimo rekomendacijos, sutrikus inkstų funkcijai

\begin{tabular}{|c|c|c|c|}
\hline Vaistas & Dozavimas & $\begin{array}{l}\text { Apskaičia- } \\
\text { vimo formulè }\end{array}$ & $\begin{array}{l}\text { Taikomas metodas: } \\
\text { aKK }(\mathrm{ml} / \mathrm{min}) \text { ar aGFG } \\
\left(\mathrm{ml} / \mathrm{min} / \mathbf{1 , 7 3} \mathrm{m}^{2}\right)\end{array}$ \\
\hline Varfarinas & $\begin{array}{l}\text { Pacientams, kurių inkstų funkcija sutrikusi, varfarino dozę gali } \\
\text { tekti mažinti arba didinti (priklausomai nuo kitų paciento ligų) }\end{array}$ & $\begin{array}{l}\text { Duomenu } \\
\text { nepateikta }\end{array}$ & $\begin{array}{l}\text { Duomenu } \\
\text { nepateikta }\end{array}$ \\
\hline Edoksabanas & $\begin{array}{l}\text { Esant lengvam inkstų funkcijos sutrikimui }(\mathrm{KK}>50-80 \mathrm{ml} / \mathrm{min}) \text {, } \\
\text { rekomenduojama dozè yra } 60 \mathrm{mg} \text { edoksabano kartą per parą; } \\
\text { Esant vidutinio sunkumo arba sunkiam inkstų funkcijos sutriki- } \\
\text { mui (KK } 15-50 \mathrm{ml} / \mathrm{min}) \text {, rekomenduojama } 30 \mathrm{mg} \text { edoksabano } \\
\text { kartą per parą; } \\
\text { Galutinėje inkstų ligos stadijoje }(\mathrm{KK}<15 \mathrm{ml} / \mathrm{min}) \text { arba dializuo- } \\
\text { jamiems edoksabano vartoti nerekomenduojama }\end{array}$ & CG & $\mathrm{KK}(\mathrm{ml} / \mathrm{min})$ \\
\hline Dabigatranas & $\begin{array}{l}\text { Esant sunkiam inkstų funkcijos sutrikimui (KK }<30 \mathrm{ml} / \mathrm{min}) \text {, } \\
\text { dabigatranu gydyti draudžiama; } \\
\text { Esant vidutinio sunkumo inkstų funkcijos sutrikimui (KK 30-50 } \\
\mathrm{ml} / \mathrm{min} \text { ), gydyti atsargiai }\end{array}$ & $\mathrm{CG}$ & $\mathrm{KK}(\mathrm{ml} / \mathrm{min})$ \\
\hline Rivaroksabanas & $\begin{array}{l}\text { Esant sunkiam inkstų funkcijos nepakankamumui (KK 15-29 } \\
\mathrm{ml} / \mathrm{min} \text { ) skiriamas atsargiai. Nerekomenduojamas pacientams, } \\
\text { kurių } \mathrm{KK}<15 \mathrm{ml} / \mathrm{min}\end{array}$ & $\begin{array}{l}\text { Duomenų } \\
\text { nepateikta }\end{array}$ & $\mathrm{KK}(\mathrm{ml} / \mathrm{min})$ \\
\hline Apiksabanas & $\begin{array}{l}\text { Pacientams, kurių KK yra }<15 \mathrm{ml} / \mathrm{min} \text { ar dializuojamiems, gy- } \\
\text { dymo šiuo vaistiniu preparatu patirties nèra, todèl jiems apiksa- } \\
\text { bano vartoti nerekomenduojama }\end{array}$ & $\begin{array}{l}\text { Duomenu } \\
\text { nepateikta }\end{array}$ & $\mathrm{KK}(\mathrm{ml} / \mathrm{min})$ \\
\hline
\end{tabular}


nurodyta, kaip dozuoti, esant inkstų funkcijos sutrikimui. Daugumai šiuo metu užregistruotų vaistų rekomendacijos pateikiamos remiantis aKK, nes registraciniuose šių vaistų tyrimuose naudota CG formulè. Svarbu atkreipti dèmesį, kokia formule, koks metodas ir matavimo vienetas yra nurodyti vaistų charakteristikų santraukoje: $\mathrm{KK}(\mathrm{ml} / \mathrm{min})$ ar $\mathrm{GFG}\left(\mathrm{ml} / \mathrm{min} / 1,73 \mathrm{~m}^{2}\right)$. Jei formule ir metodas nèra nurodyti, tuomet inkstų funkcijos skaičiavimo metodą verta rinktis atsižvelgiant ị matavimo vienetą: jei yra $\mathrm{ml} / \mathrm{min}-\mathrm{aKK}$, jei $\mathrm{ml} / \mathrm{min} / 1,73 \mathrm{~m}^{2}$ - aGFG.

Geriamųjų antikoaguliantų dozavimo rekomendacijos, esant inkstų funkcijos sutrikimui. Jei vaisto dozè netinkamai pritaikyta atsižvelgiant ị inkstų funkciją, kai ji svarbi vaisto farmakokinetikai, dozè gali būti per maža (nepakankamo veiksmingumo) arba per didelè (padidès nepageidaujamo poveikio rizika). Tai ypač svarbu vartojant antikoaguliantus, nes netinkama dozė gali sukelti tiek trombozès, tiek kraujavimo riziką ir pasekmès pacientui gali būti kritinès. 2 lentelëje nurodytos geriamujų antikoaguliantų charakteristikų santraukoje pateikiamos rekomendacijos ir pastabos dèl inkstų funkcijos vertinimo metodo. Remiantis varfarino charakteristikos rekomendacijomis, dozę sutrikus inkstų funkcijai gali tekti koreguoti, tačiau kaip dozuoti, kokią taikyti formulę ar metodą, nenurodyta. Edoksabano ir dabigatrano charakteristikų santraukose tiek formulè, tiek metodas su matavimo vienetais yra nurodyti - CG, KK (ml/ $\mathrm{min})$. Rivaroksabano ir apiksabano charakteristikų santraukose nurodytas tik metodas su matavimo vienetais - KK (ml/ min), todèl tokiu atveju taip pat reikètų rinktis CG formulę, kaip ir dozuojant edoksabaną ir dabigatraną, sutrikus inkstų funkcijai.

\section{Išvados}

Idealaus inkstų funkcijos ịvertinimo metodo nèra. Skirtingomis formulemis įvertinta paciento inkstų funkcija gali reikšmingai skirtis. Pageidautina, kad tas pats inkstų funkcijos vertinimo metodas būtų taikomas visose klinikinèse srityse (gydant inkstų ligas, vystant vaistus ir juos dozuojant). Šiuo metu užregistruotų vaistų dozavimo rekomendacijos vis dar grindžiamos aKK, todèl klinicistai, siekdami užtikrinti tinkamą dozavimą, turi būti budrūs, vertindami inkstų funkciją, nes skirtingais metodais ịvertinta inkstų funkcija gali lemti dozavimo skirtumus. Skiriant bet kokị vaistą, reikia peržiūrèti preparato charakteristikų santrauką, ịvertinti dozavimo rekomendacijas esant inkstų funkcijos sutrikimui, bei inkstų funkcijos vertinimo metodą, atkreipiant dèmesi i matavimo vienetus ir formulę, jei nurodyta. Visada būtina atsižvelgti ị klinikinę paciento būklę, nepasikliaujant formulèmis.

\section{Literatūra}

1. Millsop A. Drug dosing in patients with renal impairment and during renal replacement therapy. In: Ashley C, Morlidge C, editors. Introduction to renal therapeutics. Pharmaceutical Press 2008:127-137.

2. Corsonello A, Pedone C, Lattanzio F, Onder G, Antonelli Incalzi R; Gruppo Italiano di Farmacovigilanza nell'Anziano (GIFA): association between glomerular filtration rate and adverse drug reactions in elderly hospitalized patients: the role of the estimating equation. Drugs Aging 2011;28:379-390. https://doi.org/10.2165/11588280-000000000-00000

3. Munar MY, Singh H. Drug dosing adjustments in patients with chronic kidney disease. Am Fam Physician. 2007;75(10):1487-96.

4. Cockcroft DW, Gault MH. Prediction of creatinine clearance from serum creatinine. Nephron 1976;16(1):31-41. https://doi.org/10.1159/000180580

5. Stevens LA, Levey AS. Measured GFR as a confirmatory test for estimated GFR. J Am Soc Nephrol 2009;20(11):2305-2313. https://doi.org/10.1681/ASN.2009020171

6. Samra M, Abcar AC. False estimates of elevated creatinine. Perm J 2012;16(2):51-52. https://doi.org/10.7812/TPP/11-121

7. Levey AS, Coresh J, Greene T, et al. Using standardized serum creatinine values in the modification of diet in renal disease study equation for estimating glomerular filtration rate. Ann Intern Med 2006;145(4):247-254. https://doi.org/10.7326/0003-4819-145-4-200608150-00004

8. Levey AS, Stevens LA, Schmid CH, et al. A new equation to estimate glomerular filtration rate. Ann Intern Med 2009;150(9):604-612. https://doi.org/10.7326/0003-4819-150-9-200905050-00006

9. Kidney disease: improving global outcomes (KDIGO) CKD Work Group. KDIGO 2012 clinical practice guideline for the evaluation and management of chronic kidney disease. Kidney Int Suppl 2013;3:1-150.

10. Prabhat KN, Abhilash C. Positive and negative false estimates of serum creatinine. Interv Cardiol 2017; 9(4):163-167.

11. Matsushita K, Mahmoodi BK, Woodward M, et al. Comparison of risk prediction using the CKD-EPI equation and the MDRD study equation for estimated glomerular filtration rate. JAMA 2012; 307(18):1941-1951.

https://doi.org/10.1001/jama.2012.3954

12. Pai MP. Estimating the glomerular filtration rate in obese adult patients for drug dosing. Adv Chronic Kidney Dis 2010;17(5),e53-62.

https://doi.org/10.1053/j.ackd.2010.05.010

13. Sexton J. Drug use and dosing in the renally impaired adult. Pharmaceutical Journal 2003;271:744-746.

14. Ashley C, Currie A, editors. Renal drug handbook. 4th ed. 2014. London, Radcliffe Publishing 2014:1016.

15. Churchwell MD, Mueller BA. Selected pharmacokinetic 
issues in patients with chronic kidney disease. Blood Purif 2007;25(1):133-38.

https://doi.org/10.1159/000096412

16. Matzke GR, Aronoff GR, Atkinson AJ, et al. Drug dosing consideration in patients with acute and chronic kidney disease - a clinical update from kidney disease: improving global outcomes (KDIGO). Kidney International 2011;80(11):1122-37. https://doi.org/10.1038/ki.2011.322

17. Hart LA, Anderson GD. Methods of estimating kidney function for drug dosing in special populations. Clin Pharmacokinet 2018;57(8):943-976. https://doi.org/10.1007/s40262-018-0628-7

18. Prescribing in renal impairment. British National Formulary. Joint Formulary Committee. BMJ Group Pharmaceutical Press 2015.

19. Kuzminskis V, Skarupskiene I, Bumblyte IA, Kardauskaite Z, Uogintaite J. Comparison of methods for evaluating renal function (Data of Kaunas university of medicine hospital in 2006). Medicina (Kaunas) 2007; 43 Suppl 1:46-51.

20. Fernandez-Prado R, Castillo-Rodriguez E, Velez-Arribas FJ, et al. Creatinine clearance is not equal to glomerular filtration rate and cockcroft-gault equation is not equal to CKD-EPI collaboration equation. Am J Med 2016;129(12):1259-1263. https://doi.org/10.1016/j.amjmed.2016.08.019

21. https://www.kidney.org/content/frequently-asked-questionsabout-gfr-estimates

22. https://www.niddk.nih.gov/health-information/professionals/ clinical-tools-patient-education-outreach/ckd-drug-dosingproviders

23. Holdin MB, Petersen KK, Palm H, et al. Creatinine-based renal function estimates and dosage of postoperative pain management for elderly acute hip fracture patients. Pharmaceuticals (Basel) 2018;11(3):88.

https://doi.org/10.3390/ph11030088
24. Dowling TC, Matzke GR, Murphy JE, Burckartet GJ. Evaluation of renal drug dosing: prescribing information and clinical pharmacist approaches. Pharmacotherapy 2010;30(8):776-86. https://doi.org/10.1592/phco.30.8.776

\section{EVALUATION OF RENAL FUNCTION FOR DOSING OF MEDICINES}

\section{A. Gintautas, T. Janušonis}

Keywords: creatinine clearance, glomerular filtration rate, renal insufficiency, renal impairment, pharmacokinetics.

Summary

Renal function is particularly important in drug dosing. To avoid overdose or overdose (insufficient efficacy or adverse reactions, respectively), it is necessary to assess renal function as accurately as possible and to adjust the dose according to the recommendations presented in the summary of product characteristics. The aim of this article is to present methods of renal function assessing methods used for dosage selection based on renal function. This article reviews the methods of kidney function assessment, analyses their advantages and disadvantages and the factors influencing the results of kidney function estimation, based on the latest scientific literature data. The main principles of drug dosing in the case of renal impairment and possible contradictions are presented. It is concluded that there is no ideal method for assessing renal function, and for any medicinal product, the summary of product characteristics should be reviewed and not only the dosing recommendations for renal impairment but also the method for assessing renal function should be evaluated.

Correspondence to: armantasg@gmail.com

Gauta 2020-07-01 